\title{
AKT NOTARIALNY JAKO WYPOWIEDŹ PERFORMATYWNA
}

\author{
Piotr PIEPRZYCA, mgr \\ Wydział Filologiczny, Uniwersytet Pedagogiczny im. KEN w Krakowie \\ 30-084 Kraków, ul. Podchorążych 2 \\ ppieprzyca@gmail.com
}

\begin{abstract}
Abstrakt: Wypowiedzi performatywne - akty mowy, kształtujące rzeczywistość pozajęzykową występują często w różnego rodzaju dokumentach prawnych. Jednym z takich dokumentów jest akt notarialny, sporządzony przez notariusza i zawierający oświadczenia stron, które kreują nową rzeczywistość prawną. Nie wszystkie jednak oświadczenia w akcie notarialnym stanowią wypowiedzi performatywne - część z nich opisuje rzeczywistość, nie zmieniając stosunków cywilnoprawnych pomiędzy stronami. Szczególnym przypadkiem wypowiedzi performatywnej jest podpis stron, potwierdzający oświadczenia spisane w imieniu stron przez notariusza. Niniejsza praca ma na celu ukazanie różnorodności wyrażeń, które można zaliczyć do wypowiedzi performatywnych i tym samym ukazać, że katalog tych wyrażeń jest znacznie szerszy, niż często wskazuje się na to w literaturze językoznawczej.
\end{abstract}

Słowa kluczowe: teoria aktów mowy, wypowiedzi performatywne, akt notarialny.

\section{NOTARIAL ACT AS A PERFORMATIVE UTTERANCE}

\begin{abstract}
Performative utterances, or speech acts, shaping the extra-linguistic reality occur frequently in legal documents. One of such documents is a notarial act, drawn up by a notary and containing declarations of the parties which change the civil law relations. However, not all declarations in a notarial act are performative utterances: some of them describe the reality, without changing the civil law relations between the parties. A special case of a performative utterance is the signature of the parties, confirming the declarations written by a notary on behalf of the parties. This paper aims to illustrate the diversity of expressions which can be classified as performative utterances, and thus shows that the catalogue of these expressions is much broader than it is often presented in the linguistics literature.
\end{abstract}

Keywords: theory of speech acts, performative utterances, notarial act. 
Piotr Pieprzyca: Akt notarialny jako ...

\section{Wstęp}

Lex est quod notamus (prawem jest, co spisujemy) - nieprzypadkowo za dewizę notariuszy uznawana jest ta łacińska sentencja. Zgodnie $\mathrm{z}$ ustawą Prawo o notariacie, notariusz jest urzędnikiem, powołanym do dokonywania czynności, którym strony są obowiązane lub pragną nadać formę notarialną (czynności notarialnych - art. 1 Prawa o notariacie). Czynności prawne dokonane przez notariusza mają moc dokumentu urzędowego (art. $2 \S 2$ Prawa o notariacie). Akt notarialny jest jedną ze szczególnych form dokonywania czynności prawnych (Radwański 2005: 234), jest on sporządzany w sytuacji, gdy taka jest wola stron lub też gdy wynika to $\mathrm{z}$ przepisów prawa (jak na przykład $\mathrm{w}$ przypadku sprzedaży nieruchomości). Dokonywane przez notariusza czynności zawierają oświadczenia woli stron, mające na celu wywołanie określonych skutków cywilnoprawnych. Czynności dokonywane przed notariuszem, wpływając na zakres obowiązków i praw, zmieniają rzeczywistość prawną strony lub stron. Tak właśnie z prawniczego punktu widzenia należy interpretować przedstawioną powyżej, wywodzącą się jeszcze $\mathrm{z}$ czasów antycznego prawa rzymskiego paremię. Możemy ją jednak rozpatrywać również pod kątem językoznawczym prawo i język są ze sobą wzajemnie powiązane i niemożliwym jest uzewnętrznienie się prawa bez jego naturalnego narzędzia, jakim jest język (Pieńkos 1999: 19). Akt notarialny możemy więc uznać za wypowiedź językową, której skutki odnoszą się do rzeczywistości pozajęzykowej; jest on zatem aktem performatywnym i pod tym kątem dokonana zostanie w niniejszym artykule analiza lingwistyczna tej formy dokumentu urzędowego.

Wypowiedzi performatywne były $w$ polskim językoznawstwie przedmiotem badań i opracowań, zarówno monografii (Grodziński 1980), jak i artykułów w czasopismach naukowych (Gizbert-Studnicki 1973). Analizowane były również w kontekście prawnym (Nowak 1968; Patryas 2005; Studnicki 1969). Tematowi temu Malinowski (2006) poświęcił jeden z rozdziałów swojej monografii dotyczącej polskiego języka prawnego. Charakterystyką tych wypowiedzi w kontekście aktów notarialnych zajęła się Dunin-Dudkowska w swojej rozprawie pt. Akt notarialny jako gatunek wypowiedzi (2010), jednak w sposób dość ogólny, nie uwzględniając powiązań pomiędzy zamieszczanymi w aktach notarialnych wyrażeniami a ich konsekwencjami cywilnoprawnymi, co niewątpliwie ma znaczenie przy ustalaniu charakteru performatywnego danej wypowiedzi.

Niniejsza praca ma charakter interdyscyplinarny, juryslingwistyczny, gdyż łączy analizę językową z elementami analizy prawniczej i tym samym ukazuje relacje zachodzące pomiędzy językiem a prawem. 


\section{Przedmiot badań i opis korpusu}

Pojęcie aktu notarialnego występuje wielokrotnie w polskich źródłach prawa, jednak nie istnieje jego legalna definicja. Zgodnie z Encyklopedią PWN akt notarialny jest to dokument sporzadzony przez notariusza (osobe zaufania publicznego) $w$ formie określonej przez przepisy prawa i stwierdzajacy treść czynności prawnej (Encyklopedia PWN). Elementy, które obligatoryjnie winny być zamieszczone w każdym akcie notarialnym (bez względu na rodzaj dokonywanej tym aktem czynności prawnej) wymienia art. 92 § 1 Prawa o notariacie. Jest to między innymi dzień, miesiąc i rok sporządzenia aktu, imiona, nazwiska, imiona rodziców i miejsce zamieszkania osób fizycznych, nazwa i siedziba osób prawnych lub innych podmiotów biorących udział w akcie, podpisy biorących udział $\mathrm{w}$ akcie oraz osób obecnych przy sporządzaniu aktu i podpis notariusza. Ponadto każdy akt notarialny powinien być na wstępie oznaczony tytułem akt notarialny. W niniejszym artykule swoją uwagę skupię na elemencie wskazanym w art. $92 \S 1$ pkt 5 tej ustawy, czyli na oświadczeniach stron.

Materiał badawczy stanowić będą wybrane projekty aktów notarialnych, zamieszczone w publikacji Janeczko (2014), dotyczące czynności z zakresu prawa cywilnego najczęściej dokonywanych przez notariuszy, takich jak: umowa sprzedaży, darowizny, testament, przedwstępna umowa sprzedaży i inne (łącznie 20 dokumentów). Oprócz tego do korpusu zostały włączone autentyczne akty notarialne, sporządzone w krakowskich kancelariach w latach 2010-2015 (łącznie 20 dokumentów; wszelkie dane dotyczące przedmiotu i stron dokonujących czynności zostaną $\mathrm{w}$ artykule zmienione). Ta różnorodność źródeł ma swoje znaczenie dla niniejszej analizy. Pomimo bowiem, że każdy akt notarialny posiada pewne sztywno określone ramy oparte między innymi na wspomnianym art. $92 \S 1$ Prawa o notariacie, to jednak w przeciwieństwie do wielu innych dokumentów urzędowych, cechuje go pewna swoboda w doborze środków stylistycznych, słów i układzie tekstu. Akty notarialne sporządzane w różnych kancelariach nigdy nie są takie same, z wyjątkiem tych o krótkiej treści, obejmujących np. testament lub umowę majątkową małżeńską. $Z$ tego też względu uwzględnienie w niniejszej analizie zarówno wzorów, jak i oryginałów aktów notarialnych pozwoli na omówienie problemu wypowiedzi performatywnych w pełniejszym zakresie. 


\section{Charakterystyka wypowiedzi performatywnych w kontekście aktu notarialnego}

Pojęcie wypowiedzi performatywnych wprowadził do językoznawstwa jeden z czołowych przedstawicieli deskrypcjonizmu, John Langshaw Austin. Terminem tym określamy te wypowiedzi, w których jednocześnie z wygłoszeniem dokonuje się dana czynność (Levinson 2010, 265). Sam Austin pisał, że jeśli ktoś wygłasza wypowiedzi tego rodzaju, to powiemy, że raczej coś robi, niż tylko coś mówi (Austin 1993: 313). Wypowiedzi performatywne mogą również komunikować kogoś o czymś, wyrażać emocje lub też skłaniać inne osoby do określonego zachowania się lub działania. Te funkcje wypowiedzi performatywne pełnią jednak jedynie pośrednio, gdyż wygłaszanie ich powoduje przede wszystkim zmianę w rzeczywistości pozajęzykowej (Nowak 1968: 147).

Wypowiedzi performatywne charakteryzują się tym, że w przeciwieństwie do konstatacji - nie można im przypisać wartości logicznej prawda-fałsz (Nowak 1968: 156). Możemy o nich jedynie orzec, że są fortunne bądź niefortunne. Przykładowo, trzykrotne wypowiedzenie formuły rozwodze się $z$ toba, wypowiedziane przez mężczyznę do swojej żony w krajach, w których obowiązuje prawo koraniczne, możemy określić jako wypowiedź fortunną, czyli taką, która odnosi zamierzony skutek. Jeśli natomiast formuła ta zostanie wypowiedziana np. przez chrześcijanina czy ateistę w Polsce, sama czynność jej wygłoszenia nie spowoduje automatycznie rozwiązania małżeństwa (Levinson 2010: 266).

Wg Austina wypowiedź performatywna staje się skuteczna, jeśli spełni trzy określone warunki:

1) musi istnieć odpowiednia konwencjonalna procedura, mająca konwencjonalny skutek, a okoliczności i uczestnicy musza być odpowiedni dla sytuacji, zgodnie z wymogami procedury,

2) procedura musi zostać wykonana poprawnie $i$ w całości,

3) często uczestnicy musza mieć określone myśli, odczucia bądź zamiary, zgodnie $z$ procedura $i$ jeśli procedura przewiduje wynikajace $z$ niej zachowania, należy ich również przestrzegać (Levinson 2010: 266-267).

Biorąc pod uwagę kryterium gramatyczne, Austin wyróżnił dwa rodzaje wypowiedzi performatywnych: eksplicytne, czyli zawierające czasownik performatywny (performatyw) i implicytne (prymarne), nieposiadające takiego czasownika (Polański 1999, 645). 


\section{Comparative Legilinguistics 25/2016}

Wypowiedzi performatywne odgrywają bardzo dużą rolę w życiu społeczeństw - sakramentalne „tak” powoduje zawarcie związku małżeńskiego, formuła wypowiadana przez księdza rozgrzesza spowiadającego się, wypowiedzenie wojny wprowadza stan wojny (Zdunkiewicz 1993: 259), a zawarcie pokoju stan ten formalnie kończy. Wiele wypowiedzi performatywnych można również odnaleźć w tekstach prawnych i prawniczych. Konstytucje, ustawy, rozporządzenia i inne akty normatywne są szczególnym rodzajem wypowiedzi językowych, które wpływają na zakres praw i obowiązków adresatów norm. Przepisy w nich zawarte nie podlegają ocenie prawdziwościowej - można jedynie stwierdzić, czy zostały one prawidłowo ustanowione czy też nie (Malinowski 2006: 101).

Performatywnością cechują się jednak nie tylko akty normatywne skierowane do adresatów o określonych cechach (np. cudzoziemcach lub osobach podlegających jurysdykcji danego państwa), lecz również dokumenty prawne, w których dokonuje się zmiana praw i obowiązków indywidualnie oznaczonych podmiotów. Sam Austin jako przykład wypowiedzi performatywnej w swojej rozprawie pt. Jak działać słowami podał zdanie zaczerpnięte z testamentu: Mój zegarek daję i zapisuję w spadku mojemu bratu (Austin 1993: 554). Zresztą w dalszej części wywodu autor ten jako termin najbardziej zbliżony do wypowiedzi performatywnych podaje wyrażenie dokonawcze - pojęcie z zakresu prawa, odnoszące się to tych klauzul dokumentu, które stuża przeprowadzaniu transakcji (Austin 1993: 554).

Jednym z takich dokumentów prawnych, które za pomocą wypowiedzi językowych zmieniają rzeczywistość pozajęzykową, są akty notarialne. Jest to szczególny rodzaj dokumentu, który stanowi formę dokonywania różnego rodzaju czynności cywilnoprawnych. W przeciwieństwie do aktów normatywnych mających charakter ogólny, akty notarialne zawierają wypowiedzi o charakterze szczegółowym, dotyczą bowiem tylko i wyłącznie oznaczonych indywidualnie w tym dokumencie osób fizycznych bądź prawnych. Akt notarialny zawiera oświadczenia stron, które zmieniają rzeczywistość pozajęzykową. Mogą być one skuteczne (fortunne) gdy powodują zmianę w stosunkach cywilnoprawnych, lub też nieskuteczne (niefortunne), gdy ze względu na niespełnienie prawem określonych warunków nie odnoszą zamierzonego przez stronę lub strony dokonywanej czynności skutku prawnego.

Grodziński stwierdza, że dla powstania nowego stosunku prawnego konieczne jest, aby treść wypowiedzi performatywnej była znana innym osobom, nie tylko jej autorowi, bowiem wypowiedź performatywna znana tylko jej autorowi pozostaje całkowicie nieskuteczna (Grodziński 1980: 30). W przypadku aktu notarialnego warunek ten zostaje zawsze spełniony, bowiem treść aktu zawsze jest znana co najmniej dwóm osobom - stronie dokonywanej czynności 
oraz notariuszowi. Niemożliwe jest sporządzenie przez notariusza aktu notarialnego, w którym sam byłby stroną dokonywanej czynności. Należy jednak zwrócić uwagę, iż wypowiedź performatywna nie musi być znana osobie, której wypowiedź ta bezpośrednio dotyczy, a pomimo to wypowiedź taka będzie skuteczna. Istnieją bowiem w prawie cywilnym czynności jednostronne, które kreują nową rzeczywistość prawną bez konieczności poinformowania o tej czynności drugiej osoby. Przykładowo, powołanie w testamencie danej osoby do dziedziczenia jest skuteczne również wtedy, gdy spadkobierca nie wie o istnieniu tego dokumentu w chwili jego sporządzania.

Grodziński zwraca uwagę na jeszcze jeden ważny aspekt wypowiedzi performatywnych w prawie, jakim jest intencja autora tej wypowiedzi. Wymienia on trzy rodzaje nieprawidłowości intencji:

- gdy autor chce celowo wprowadzić w błąd innych (podstęp),

- gdy autor działa pod wpływem błędu, w który został wprowadzony przez innych,

- gdy autor działa pod wpływem groźby lub przymusu (Grodziński 1980: 32).

Natomiast polski Kodeks cywilny w art. 82-88 wymienia następujące wady oświadczenia woli: stan wyłączający świadome albo swobodne powzięcie decyzji i wyrażenie woli, pozorność, błąd, zniekształcenie przez posłańca, podstęp i groźbę. Trudno nie dostrzec tu podobieństwa między podanymi wyżej nieprawidłowościami intencji a wadami oświadczenia woli - katalog jednych i drugich w znacznej mierze pokrywa się. Szczegółowa charakterystyka oświadczeń woli pod kątem interesującego nas zagadnienia performatywności zostanie dokonana w następnym rozdziale.

\section{Performatywność oświadczeń woli}

W doktrynie prawa cywilnego wyróżnia się oświadczenia wiedzy i oświadczenia woli. Pierwsze $\mathrm{z}$ nich są zdarzeniami polegającymi na przekazaniu informacji przez podmiot na podstawie posiadanej przez niego wiedzy na dany temat; oświadczenia te co do zasady nie wywołują skutków prawnych (Radwański 2005: 219). W aktach notarialnych oświadczeniem wiedzy jest na przykład następujące zdanie:

\section{Przykład 1.}

Jan Kowalski oświadcza, że jest nadal właścicielem przedmiotowej nieruchomości $w$ stanie wolnym od wszelkich obciażeń, praw i roszczeń osób trzecich. 
Oświadczenia wiedzy mogą dotyczyć między innymi stanu prawnego przedmiotu umowy lub stanu cywilnego stron umowy. Mogą również dotyczyć uprzednio dokonanych przez stronę czynności (Przykład 2) lub też stanu faktycznego nieruchomości (Przykład 3):

\section{Przykład 2.}

Jan Kowalski oświadcza, że $w$ odniesieniu do spadku po Marii Kowalskiej nie zostało uprzednio wydane postanowienie o stwierdzeniu nabycia spadku $i$ nie toczy sie postępowanie o stwierdzenie nabycia spadku ani nie zostat sporzadzony akt poświadczenia dziedziczenia.

\section{Przykład 3.}

Jan Kowalski oświadcza, że zbywana dziatka jest zabudowana budynkiem mieszkalnym, murowanym, krytym dachówka, 4-izbowym oraz budynkiem gospodarczym i stodoła pod jednym dachem, kryte blacha.

W związku z tym, że oświadczenia wiedzy mają jedynie służyć opisowi rzeczywistości na podstawie posiadanych przez podmiot informacji, wypowiedzi te nie mają charakteru performatywnego.

Inaczej sytuacja przedstawia się w przypadku oświadczeń woli. Zgodnie z art. 60 Kodeksu cywilnego:

$Z$ zastrzeżeniem wyjątków $w$ ustawie przewidzianych, wola osoby dokonującej czynności prawnej może być wyrażona przez każde zachowanie się tej osoby, które ujawnia jej wole w sposób dostateczny, w tym również przez ujawnienie tej woli $w$ postaci elektronicznej (oświadczenie woli).

Jak stwierdza Radwański:

Oświadczenie woli (...) zawiera treść czynności prawnej, określająca jej konsekwencje prawne. Wbrew sugestii płynacej z potocznego znaczenia tego terminu nie odnosi się on do wypowiedzi sprawozdawczych, informujacych o treści przeżyć psychicznych czlowieka. Sens oświadczenia woli ustala się na podstawie regut znaczeniowych zastosowanych do zachowania się człowieka. Jeżeli $w$ ten sposób ustalone znaczenie wskazuje na to, że dokonuje on regulacji (ustanawia jakaśs zmianę $w$ stosunkach cywilnoprawnych), należy uznać, że złożone 
Piotr Pieprzyca: Akt notarialny jako ...

zostało oświadczenie woli wjurydycznym tego stowa znaczeniu (Radwański 2005: 219).

Przykładem takiej czynności może być ustanowienie ograniczonego prawa rzeczowego - służebności osobistej:

\section{Przyklad 4.}

Jan Kowalski ustanawia stużebność mieszkania $w$ catym lokalu mieszkalnym $n r 1$ os. Lingwistyczne 2 w Krakowie na rzecz matki Ewy Kowalskiej-nieodpłatnie i dożywotnio.

Pomimo tego, że pojęcie wypowiedzi performatywnej zostało wypracowane w językoznawstwie, a oświadczenia woli - w doktrynie prawnej, można zauważyć wiele podobieństw pomiędzy ich definicjami. Oświadczenie woli, złożone pisemnie lub ustnie, można bowiem potraktować jako szczególny przykład lub też, mówiąc ściślej - podtyp wypowiedzi performatywnej, której skutki są dostrzegalne w rzeczywistości pozajęzykowej, cywilnoprawnej. Przykładem oświadczenia woli jest powołanie do dziedziczenia w testamencie sporządzonym $\mathrm{w}$ formie aktu notarialnego:

\section{Przyklad 5.}

Jan Kowalski oświadcza, że do całości spadku powotuje swojego syna, Władystawa Kowalskiego, syna Jana i Anieli, PESEL 97080288333.

W wyżej przedstawionym zdaniu (Przykład 5), zaczerpniętym z testamentu sporządzonego $\mathrm{w}$ formie aktu notarialnego, powotuje jest czasownikiem performatywnym zmieniającym rzeczywistość w ten sposób, że wskazanej w tym akcie osobie przysługiwać będzie spadek po testatorze na podstawie dziedziczenia testamentowego. Warto tutaj nadmienić, iż $\mathrm{w}$ polskim prawie cywilnym akceptowane są również inne niż akt notarialny formy testamentu, na przykład testament własnoręczny (holograficzny), czy też, w szczególnych okolicznościach, testament ustny. W tym wypadku samo wypowiedzenie określonej formuły przy spełnieniu określonych w przepisach warunków wystarczy do powstania nowych praw i obowiązków.

Obszerną listę czasowników performatywnych podaje w swojej monografii Dunin-Dudkowska (2010). Oto niektóre z nich:

udziela (petnomocnictwa); uzycza (samochodu); sprzedaje (nieruchomość); przejmuje (dtug); oddaje (w używanie); przenosi 
(własność); rozszerzaja (wspólność majątkowa); poddaje się (rygorowi egzekucji) (Dunin-Dutkowska 2010: 87).

W związku z tym, że akt notarialny jest sporządzany przez notariusza, nie będącego stroną dokonywanych czynności, dokument ten zawiera performatywy głównie w trzeciej osobie liczby pojedynczej lub mnogiej (w zależności od tego, ile osób bierze udział w czynności), zazwyczaj w czasie teraźniejszym. Znacznie mniej liczne są czasowniki w trzeciej osobie liczby pojedynczej czasu przyszłego, np. stanowic bedzie ich majątek objęty wspólnością i inne formy, tj. czasowniki modalne, konstrukcje w stronie biernej oraz imiesłowy przysłówkowe współczesne (Dunin-Dutkowska 2010: 87-88). Sporadycznie są również używane czasowniki w pierwszej osobie liczby pojedynczej, np. w protokole otwarcia i ogłoszenia testamentu:

\section{Przykład 6.}

$W$ roku dwa tysiace piętnastym we wrześniu dnia dwudziestego piatego 12015-09-25/, ja - notariusz Piotr Nowak prowadzacy Kancelarie Notarialna w Krakowie przy ul. Lingwistycznej 1, działajac na podstawie art. 649 \$ 1 kodeksu postępowania cywilnego i art. $104 \S 3$ ustawy Prawo $o$ notariacie, dokonałem otwarcia $i$ ogłoszenia testamentu Jana Kowalskiego (...).

Warto zwrócić uwagę, iż czasownik w wyżej podanym przykładzie użyty został w czasie przeszłym i aspekcie dokonanym. Rodzi więc to wątpliwość, czy czasownik ten może zostać uznany za performatyw, skoro jego forma sugeruje, że dane zdarzenie już nastąpiło, a nie następuje. Jeśli weźmiemy jednak pod uwagę kontekst wypowiedzi i rodzaj dokumentu, w którym czasownik ten został użyty - protokól otwarcia i ogłoszenia testamentu, czyli akt notarialny, w którym notariusz dokonuje otwarcia i ogłoszenia testamentu, możemy wywnioskować, iż de facto czasownik ten odnosi się do czynności, która jest dokonywana poprzez użycie właśnie tego wyrażenia. Wynika $\mathrm{z}$ tego, że podany $\mathrm{w}$ powyższym przykładzie czasownik ma charakter performatywny.

Czasowniki performatywne w pierwszej osobie liczby pojedynczej są częste w tekstach innych czynności notarialnych, które jednak aktami notarialnymi nie są, np. w czynnościach poświadczeniowych, wymienionych w art. 96 Prawa o notariacie. Przykładową czynnością tego typu jest poświadczenie własnoręczności podpisu:

\section{Przykład 7.}


Poświadczam, że: Jan Kowalski, syn Jana i Marii /Pesel: 33010100100/, zamieszkaty: 33-333 Kraków ul. Lingwistyczna nr 1, którego tożsamość ustalitem na podstawie dowodu osobistego serii: ABC 123456, powyższy dokument $w$ mojej obecności $w$ Kancelarii Notarialnej w Krakowie - wtasnoręcznie podpisat.

Innym przykładem czynności notarialnej zawierającej taką formę performatywu jest akt poświadczenia dziedziczenia, mający moc prawną prawomocnego postanowienia sądowego o stwierdzeniu nabycia spadku:

\section{Przyklad 8.}

$W$ roku dwa tysiace piętnastym we wrześniu dnia dwudziestego piatego 12015-09-25/, ja - Piotr Nowak notariusz prowadzacy Kancelarię Notarialna $w$ Krakowie przy ul. Dtugiej 1(..) poświadczam, że spadek po Janie Kowalskim nabyła wprost córka Zofia Kowalska (...).

Grodziński stwierdza, że performatywy tak naprawdę winny być wygłaszane w pierwszej osobie, gdyż przetwarzać rzeczywistość tworzac nowe stosunki prawne, można wytacznie przemawiając w pierwszej osobie (Grodziński 1980: 37). Czasowniki w trzeciej osobie mają zdaniem tego autora jedynie charakter skrótowo-zastępczy, wtórny wobec właściwego performatywu. Trudno jednak wyobrazić sobie np. akt notarialny umowy sprzedaży, w którym oświadczenia woli stron byłyby sformułowane w pierwszej osobie liczby pojedynczej, skoro sam akt jest sporządzany przez notariusza. Jednocześnie nie w sposób odmówić wypowiedziom zawartym w aktach notarialnych waloru performatywności, pomimo użycia formy trzeciej osoby, bowiem posiadają one wszystkie cechy niezbędne do zaliczenia ich do wypowiedzi performatywnych kreują nową rzeczywistość poprzez powstanie nowych praw i obowiązków.

Należy również zwrócić uwagę, że czasowniki performatywne, które jednocześnie stanowią dokonywaną aktem notarialnym czynność prawną mogą być poprzedzone czasownikiem wprowadzającym mowę zależną, tak jak w podanym niżej przykładzie oświadczenia zawartego w umowie darowizny:

\section{Przykład 9.}

Anna Kowalska oświadcza, że daruje Alicji Kowalskiej nieruchomość położona $w$ Krakowie, $d z$ adm. Krowodrza, obręb 1, utworzona z jedynej niezabudowanej dziatki $\mathrm{nr}$ 1/1 obszaru 0,1100 ha, a Alicja Kowalska oświadcza, że darowiznę te przyjimuje. 
Możliwe jest jednak pominięcie takiej konstrukcji i przejście bezpośrednio do performatywu określającego czynność prawną:

\section{Przyklad 10.}

Anna Kowalska daruje Alicji Kowalskiej nieruchomość położona $w$ Krakowie, $d z$ adm. Krowodrza obręb 1, utworzona $z$ jedynej niezabudowanej dziatki nr 1/1 obszaru 0,1100 ha, a Alicja Kowalska darowiznę tę przyimuje.

\section{Podpis jako wypowiedź performatywna}

Kontynuując nasze rozważania dotyczące charakteru performatywnych wypowiedzi, powinniśmy odpowiedzieć na jedno jeszcze pytanie: skoro będące performatywami oświadczenia woli formułowane są w aktach notarialnych prawie zawsze poprzez czasowniki w trzeciej osobie, co sprawia, że oświadczenia te możemy uznać za wypowiedzi stron dokonywanych czynności? Otóż łącznikiem pomiędzy stronami dokonywanych czynności prawnych a ich oświadczeniami woli jest ich podpis na akcie notarialnym. Zgodnie z art. 92 $\S 1$ pkt 8 i 9 Prawa o notariacie, akt notarialny powinien zawierać podpisy osób biorących udział w akcie, osób obecnych przy sporządzaniu aktu oraz podpis notariusza. Jak Stwierdza Oleszko, podpis służy identyfikacji osoby, która go składa, oraz indywidualizacji treści oświadczenia pochodzącego od tej osoby (Oleszko 2012: 127).

Na poziomie leksykalnym podpis składa się z rzeczowników: imienia i nazwiska. Pod względem pragmatycznym podpis oznacza jednak coś więcej gdybyśmy mogli sformułować pełną treść wypowiedzi zawartej w podpisie, brzmiałaby ona mniej więcej tak:

Ja, Jan Kowalski oświadczam, że:

- notariusz odczytat treść niniejszego aktu notarialnego,

- zrozumiatem jego treść i znaczenie,

- jest zgodny z moja wola i akt ten zostat przeze mnie przyjęty.

Złożenie podpisu przez strony na akcie notarialnym powoduje nadanie mu mocy prawotwórczej (Oleszko 2012: 128). Jest to więc szczególny przypadek prymarnej wypowiedzi performatywnej.

Sytuacja jest odmienna wtedy, gdy strona nie jest w stanie własnoręcznie się podpisać imieniem i nazwiskiem np. w sytuacji, gdy jest niepiśmienna. 
W takim przypadku prawo o notariacie (art. $87 \S 1$ pkt 4 Prawa o notariacie) przewiduje pobranie tuszowego odcisku palca, w praktyce najczęściej kciuka. Odcisk palca jest nośnikiem tej samej treści, co podpis, jednak ze względu na to, iż nie jest formułowany za pomocą języka, nie można uznać go za wypowiedź performatywną.

Zupełnie inną treść mają podpisy osób nie będących stroną dokonywanej w akcie czynności, lecz biorących udział w akcie, np. podpis tłumacza przysięgłego będzie nośnikiem następującej treści:

Ja, Jan Kowalski, tłumacz przysięgły języka B oświadczam, że niniejszy akt notarialny zostat przeze mnie w całości przettumaczony z języka A na język B stawającemu do tego aktu XY, biegle wtadajacemu językiem B.

Należałoby jeszcze rozważyć, jaką strukturę głęboką można przypisać podpisowi notariusza. Biorąc pod uwagę rolę notariusza w polskim systemie prawnym oraz art. 81 Prawa o notariacie, który stanowi, że notariusz ma obowiązek odmówić dokonania czynności sprzecznej $\mathrm{z}$ prawem, podpis notariusza jest równoważny z wypowiedzią o następującej treści:

Ja, notariusz Jan Kowalski, powaga swojego urzędu poświadczam, że:

- czynność prawna dokonywana przez strony niniejszym aktem, nie jest sprzeczna z prawem,

- wszelkie warunki konieczne do dokonania tej czynności zostaty spetnione,

- czynność ta jest zgodna wola stron,

- z chwila podpisania niniejszego aktu przez osoby biorace udziat w czynności, osoby obecne przy sporzadzaniu aktu oraz notariusza to, co spisano, stanowi prawo.

\section{Podsumowanie}

Niniejsza analiza wykazała, iż akt notarialny jest formą wypowiedzi, zawierającą wyrażenia performatywne zmieniające rzeczywistość pozajęzykową rzeczywistość prawną. Performatywnością cechują się przede wszystkim oświadczenia woli stron dokonywanych czynności, a także - w niektórych przypadkach - oświadczenia notariusza. W przeciwieństwie do nich, oświadczenia wiedzy co do zasady takiego waloru nie posiadają. Czasowniki performatywne najczęściej mają formę trzeciej osoby czasu teraźniejszego, co 
wynika ze specyfiki aktu notarialnego, który jest dokumentem zawierającym oświadczenia stron. Sporadycznie zdarzają się też czasowniki w innej formie, np. w pierwszej osobie czasu przeszłego, gdy notariusz w treści aktu opisuje czynności dokonywane przez siebie na rzecz osób trzecich. Charakter performatywny mają również zamieszczone na końcu dokumentu podpisy stron, które potwierdzają, że akt jest zgodny z wolą stron i nadają aktowi notarialnemu moc prawotwórczą.

Ze względu na fakt, iż w formie aktu notarialnego można dokonywać niemal każdej czynności cywilnoprawnej, której strony pragną nadać formę notarialną, katalog wypowiedzi performatywnych zawartych w tych dokumentach jest nieograniczony. Nawet akty notarialne dokumentujące te same czynności mogą zawierać inaczej sformułowane performatywy, co jest widoczne, gdy porównamy przedstawiony w niniejszym artykule Przykład 9, pochodzący $\mathrm{z}$ autentycznego aktu notarialnego i Przykład 10, zaczerpnięty $\mathrm{z}$ publikacji Janeczko (2014). Wymienione przykłady ilustrują również ogólną tendencję polegającą na tym, że w porównaniu z wzorami aktów notarialnych (Janeczko: 2014), w aktach sporządzanych w kancelariach notarialnych zdania znacznie częściej rozpoczynają się od wyrażenia: $X$ oświadcza, że... Ten zabieg lingwistyczny ma na celu uchronić notariusza przed negatywnymi konsekwencjami w przypadku, gdy oświadczenia woli okażą się nieskuteczne, a oświadczenia wiedzy - nieprawdziwe.

$\mathrm{Z}$ pewnością zagadnienie wypowiedzi performatywnych $\mathrm{w}$ języku prawnym i prawniczym jest zagadnieniem niezwykle obszernym i, pomimo licznych publikacji, ciągle niewyczerpanym. Wypowiedzi performatywne występują również niezwykle licznie w ustawach, decyzjach administracyjnych, wyrokach sądowych itp. Niniejszy artykuł, koncentrując się na drobnym wycinku zdarzeń cywilnoprawnych, jakim są czynności dokonywane w formie aktu notarialnego, jednocześnie odsłania perspektywę do dalszych badań wypowiedzi performatywnych w prawie, uwzględniających inne teksty prawne i prawnicze.

\section{Bibliografia}

Austin, John Langshaw. 1993. Mówienie $i$ poznanie: rozprawy $i$ wyktady filozoficzne. Warszawa: Wydawnictwo Naukowe PWN.

Dunin-Dudkowska, Anna. 2010. Akt notarialny jako gatunek wypowiedzi. Lublin: Wydawnictwo UMCS.

Encyklopedia

$P W N$.

http://encyklopedia.pwn.pl/haslo/aktnotarialny;3867029.html (data dostępu: 1 września 2015). 
Gizbert-Studnicki, Tomasz. 1980. Czym nie sa wypowiedzi performatywne. Studia Filozoficzne 8/1980: 121-129.

Grodziński, Eugeniusz. 1980. Wypowiedzi performatywne. Wrocław: Zakład Narodowy im. Ossolińskich.

Janeczko, Edward. 2014. Wzory aktów notarialnych. Warszawa: Wydawnictwo Prawnicze LexisNexis.

Levinson, Stephen. 2010. Pragmatyka. Warszawa: Wydawnictwo Naukowe PWN.

Malinowski, Andrzej. 2006. Polski język prawny. Wybrane zagadnienia. Warszawa: Wydawnictwo Prawnicze LexisNexis.

Nowak, Leszek. 1968. Performatywy a język prawny i etyczny. Etyka 3: 147-56.

Oleszko, Aleksander. 2012. Prawo o notariacie. Komentarz. Część II. Tom 1-2. Warszawa: Wydawnictwo Prawnicze LexisNexis.

Patryas, Wojciech. 2005. Performatywy w prawie. Poznań: Wydawnictwo Forum Naukowe.

Pieńkos, Jerzy. 1999. Podstawy juryslingwistyki. Język w prawie - prawo w języku. Kraków: Oficyna Prawnicza MUZA.

Polański, Kazimierz, red. 1999. Encyklopedia językoznawstwa ogólnego. Wrocław: Zakład Narodowy im. Ossolińskich.

Radwański, Zbigniew. 2005. Prawo cywilne - część ogólna. 8 wydanie. Warszawa: Wydawnictwo C.H. Beck.

Studnicki, Franciszek. 1969. O wypowiedziach dokonawczych. Studia Cywilistyczne 23-24: 343-53.

Zdunkiewicz, Dorota. 1993. Akty mowy. W Encyklopedia kultury polskiej XX wieku, t. II: Współczesny język polski. Red. Jerzy Bartmiński, 259-270. Wrocław: Wiedza o Kulturze.

Ustawy:

Ustawa z dnia 23 kwietnia 1964 r. Kodeks cywilny (Dz. U. 2014 poz. 121). Ustawa z dnia 14 lutego 1991 r. Prawo o notariacie (Dz. U. 2014 poz. 164). 